Article

\title{
Making Nothing Happen: Yeats, Heidegger, Pessoa, and the Emergence of Post-Romanticism
}

\author{
James Corby \\ Department of English, Faculty of Arts, University of Malta, Msida, MSD 2080, Malta; \\ E-Mail: james.corby@um.edu.mt; Tel.: +356-2340-2613
}

Received: 19 August 2012; in revised form: 20 September 2012 / Accepted: 24 September 2012 /

Published: 1 October 2012

\begin{abstract}
Through close readings of the work of two major poets of the twentieth century-W.B. Yeats and Fernando Pessoa - this paper identifies and attempts to make sense of an important shift in European modernism away from a broadly Romantic aesthetic toward what might be called "post-Romanticism." Taking its cue from W.H. Auden's "In Memory of W.B. Yeats," where having stated that "poetry makes nothing happen" he asserts that it survives as "a way of happening," and drawing on the philosophy of Heidegger and Jean-Luc Nancy, this paper argues that this shift from Romanticism to post-Romanticism hinges on a deep metaphysical reconceptualization of poetry understood as poiesis. In light of this reassessment of the aesthetics and philosophical affinities of poetic modernism, it is argued that post-Romanticism should be understood as offering a modest, salutary, phenomenological re-acquaintance with our involvement with the everyday world, in sharp contrast to the transcendental ambitions of the Romantic aesthetic that preceded it.
\end{abstract}

Keywords: poetry; poiesis; romanticism; Auden; Yeats; Heidegger; Pessoa; Nancy; phenomenology; aesthetics

\section{Introduction}

In the poem "In Memory of W.B. Yeats," W.H. Auden (1907-1973) famously writes:

For poetry makes nothing happen: it survives

In the valley of its saying where executives

Would never want to tamper; it flows south 
From ranches of isolation and the busy griefs,

Raw towns that we believe and die in; it survives,

A way of happening, a mouth. ([1], p. 82)

Let us isolate each of the claims Auden is here making about poetry: first, poetry makes nothing happen, second, it survives in the valley of its saying (or, according to a later version of the poem, its making ([2], p. 246)), and, third, it is, in this regard - that is, in its surviving - a way of happening, a mouth. Poetry, then, makes nothing happen but is a saying/making and this saying/making is a way of happening. This might prompt us to ask: what is a making which does not make anything happen but is a way of happening? Given poetry's etymological root in poiesis - or making/bringing-forth - this question, and, indeed, Auden's view of poetry, become even more pointed and intriguing. As he has The Counsel for the Defense put it in "The Public v. the late Mr William Butler Yeats," "art is a product of history, not a cause" ([3], p. 393).

I would like to suggest that this shift in emphasis away from poetry as a making happen to a way of happening indicates an increased accentuation on the understanding of poetry as poiesis that might be understood as a constitutive difference between Romanticism and what I will call post-Romanticism. Moreover, I will argue that this shift in emphasis - and thus the transition from Romanticism to postRomanticism - is brought into focus by Yeats's own poetic development, which can perhaps be read as representative of a more general trend in British and European poetry during the twentieth century. I will conclude with an attempt to instantiate this post-Romanticism more fully with reference to the work of Portuguese poet Fernando Pessoa (1888-1935), which I argue is exemplary in this regard.

Yeats (1865-1939), of course, was, for much of his life, convinced of poetry's effective powerpoetry does make something happen. This belief was the main force driving some of his most powerful middle period poetry. But what, for the Yeats of this period, does poetry make happen? What, in other words, does poetry do? For the Yeats of The Tower [4], the highest achievement of poetry is to render present in verse that which is antithetical to the self, momentarily utterly disrupting the subjectivity and control of the poet and thereby revealing the incomprehensible absolute that lies beyond his conceptualizing grasp. The incorporation of these disruptive visionary passages of poetry developed slowly over time but comes to full fruition in apocalyptic sequence poems such as "Meditations in Time of Civil War" and "Nineteen Hundred and Nineteen" where, in the seventh and sixth sections respectively, the order and calm that on the whole characterize the poems are violently overturned, giving way instead to strange visionary writing until calm and order just as suddenly return. In this regard, Yeats's conviction about what poetry does - namely, that it gestures beyond to a realm which is not accessible to nor compatible with ordinary reflective consciousness - positions his middle period poetry, I would suggest, as a late (though by no means uncommon) manifestation of a particular form of Romantic aesthetics [5]. Though echoes of this form of Romanticism are heard in English poetryquite clearly so in the cases of Coleridge's "Dejection: An Ode" [6] and Wordsworth's "Ode ("There was a time')" [7] - its true home is European Romanticism, particularly that which found expression in Germany at the end of the eighteenth century. 


\section{Early German Romanticism}

German Romanticism emerged out of a crisis in philosophy. Since Descartes's thought-experiment of radical skepticism and the consequent positioning of a reflective, self-certain subject at the heart of thought, questions of epistemology became increasingly entangled with questions of subjectivity [8-13]. If the self is in a constant, reflective relationship with itself in all its cognitive operations, it can seemingly never, as it were, free itself from itself in order to know either itself in its totality or things as they are in themselves. Thus, because thought cannot, without remainder, think its own reflective ground, an apparent split arises between the thinking subject and the thought object - a split out of which the threat of skepticism and, indeed, nihilism, can emerge. In Germany, toward the end of the eighteenth century, these limitations of reflective thought led J.G. Fichte (1762-1814)—who supported Kant's critical endeavors, while judging them inadequately expressed - to posit something underlying and making possible all thought [14]. However these same limitations prevented him from ever giving a full and adequate account of what that something is. In reacting to the work of Fichte, the early German Romantics took as their starting point this conflict between the realization that reflective consciousness is inherently limited and therefore taints all putatively objective knowledge, on the one hand, and the continuing desire to know the unifying absolute beyond these limitations, on the other. Feeling torn between what Fichte calls "the incapacity and the demand" ([14], p. 201) ("dem Unvermögen und der Forderung" ([15], p. 225)), they cultivated the belief that although this "beyond" apparently cannot be accessed by philosophy, by artistically performing the failure of reflective thought and thereby rupturing the subjectivism of thought's finite, conceptualizing grasp, a space might be created in the artwork in which that which exceeds ordinary consciousness-variously referred to as the absolute, being, or the unconditioned-may come forth and show itself in all of its strangeness and ungraspability. Of course, this rupture would provide no substantive alternative to the rational, reflective and everyday, and it risks being immediately co-opted by one's subjective, conceptualizing grasp. ${ }^{1}$ Thus, in the wake of philosophy's seemingly futile endeavors, the most that can be achieved for Friedrich Schlegel (1772-1829) (and, to some degree, for Novalis (1772-1801) and perhaps even for Hölderlin (1770-1843)), using terminology influenced by Fichte even as he rebels against him, is an alternating proof (Wechselerweis), a wavering (Schweben) between the world we know and the pure world beyond, a wavering between our subjectivism and a pure objectivity, between determinacy and indeterminacy, between the I and the not-I (in Yeatsian language, the self and the anti-self) or, to put it in more metaphorical, Blanchotian language, ${ }^{2}$ between the day and a night that is completely other, between life and a visionary, Orpheus-like death ([14], pp. 193-195; [16], pp. 175-176; [17]; [4], pp. 264-266; [18], pp. 163-170). Unable to get beyond one's subject/object perspective in order to grasp the world as it is in itself, this sense of something beyond, something utterly different - for Yeats the antithetical self — is perhaps as close as one can get to the absolute, which, as Lacoue-Labarthe and Nancy point out, should in this context be understood as the unconditioned self-making (that is, autopoietic) whole from which reflection seems to alienate us [19].

1 Hegel, about whom I will say more later, thought that the reality of Romanticism was far more damning than these imagined risks.

2 The influence of the early German Romantics on Blanchot was very significant and a compelling case could be made for him to be considered the most important late-Romantic theorist of the twentieth century. 
And it is this context, and these ideas, that form the basis of what might be called Romanticism's aesthetics of failure. This widely influential understanding and configuration of art emerged in the belief that in response to the apparent limitations of philosophical investigation, a sort of heightened experience or apophatic insight might be achieved by means of artworks that somehow perform artistically and productively the failure of reflective consciousness.

For Schlegel, perhaps the most important theorist of early German Romanticism, the moment of indeterminate otherness in the artwork constitutes the "real" in contrast to the idealism of one's subjective perspective ([20], p. 83). ${ }^{3}$ It is the task of poetry-since poetry is capable of this, unlike philosophy - to hover, alternating between the real and the ideal. In the Athenaeum fragments he calls this "transcendental poetry" ([16], p. 195) ("Transzendentalpoesie" [21], p. 204). To achieve this, Schlegel believes that an absolute indeterminacy must be built into an otherwise determinate artwork so that the work alternates undecidedly between the two, teetering on the verge of collapse. This is the moment of the work's self-critique: the dynamic between determinacy and dissolution is the critical unworking that is the work of the Romantic work ([22], p. 357). In this critical moment the work ruptures its (that is to say, our) subjective, conceptualizing grip on the world. Ironically, therefore, it is precisely this rupture, this dissolution in indeterminacy of the seemingly objective, that constitutes an objective moment in the Romantic artwork. As such, in the apparent breakdown of the artwork, we are momentarily carried (by the work) beyond ourselves and our perspectival finitude. In that brief moment the self-critical work opens us to what we are not by performing its own failure, which is also our own failure. Failure, then - and this is perhaps the central paradox undergirding early German Romanticism - is something to be achieved. In this sense, the Romantic artwork should be both complete and incomplete - indeed, incompletable - where "it is everywhere sharply delimited, but within those limits limitless and inexhaustible" ([16], p. 204) ("es überall scharf begrenzt, innerhalb der Grenzen aber grenzenlos und unerschöpflich ist” [21], p. 215). The fragmentary ideal of the Romantic work is to be endlessly becoming in self-critical dissolution. This is what Schlegel means when he argues that Romantic irony should be employed to bring the artwork "to the point of continuously fluctuating between self-creation and self-destruction" ([16], p. 167) ("zum steten Wechsel von Selbstschöpfung und Selbstvernichtung” [21], p. 172). Similarly, Schlegel also writes: "An idea is a concept perfected to the point of irony, an absolute synthesis of absolute antitheses, the continual self-creating interchange of two conflicting thoughts" ([16], p. 176) ("Eine Idee ist ein bis zur Ironie vollendeter Begriff, eine absolute Synthesis absoluter Antithesen, der stete sich selbst erzeugende Wechsel zwei streitender Gedanken" ([21], p. 184)). As Blanchot makes clear, the point of the self-critical Romantic fragment is not to realize the whole but to signal it by suspending it ([22], p. 353). "Only what is incomplete ... can take us further", as Novalis says ([23], p. 65). It is to this tradition that much Romantic and so-called Modernist literature belongs and to which, I think, Yeats's vision poems are best understood as belonging. For Yeats, this is what poetry makes happen.

Schlegel writes: "Der Idealismus in jeder Form muß auf ein oder die andre Art aus sich herausgehn, um in sich zurückkehren zu können, und zu bleiben was er ist. Deswegen muß und wird sich aus seinem Schoß ein neuer ebenso grenzenloser Realismus erheben” ([21], p. 315). 


\section{Yeats's and T.E. Hulme's Rejection of the Romantic Aesthetics of Failure}

It might be argued that Yeats's attachment to this Romantic aesthetics of failure is anachronistic. Indeed, after Hegel's trenchant critique of this view of what art—and particularly poetry — does, in his lectures on aesthetics (about which more will be said later), it is extremely difficult to see how it can be regarded as anything other than metaphysically mistaken. Interestingly, Yeats himself comes to share the view that the Romantic belief in what it is that poetry is capable of doing is exaggerated and unjustifiable, and he becomes disenchanted with his own Romantic visionary poetry. However, this loss of faith in what poetry can make happen does not lead him to stop writing poetry. On the contrary, Yeats rejects the Romantic aesthetics of failure poetically. This is significant because it suggests that whereas for Hegel the failure of Romanticism marked a more general decline or end of art, for Yeats poetry's loss of effectiveness - the collapse of the claim that it makes something happen - might not necessarily signal an end of art. It might instead open up the possibility of a transformed understanding of poetic efficacy - a transformation, in other words, of how poetry as poiesis is understood.

Yeats's late poems give an indication of what such distinctly post-Romantic poetry might look like. His mounting disillusionment is evident in his 1936 poem, "An Acre of Grass." He still hopes for visionary inspiration (“Grant me an old man's frenzy, / Myself must I remake...”) but, like Hegel, for him such poetry, poetry of frenzied imagination and extravagant metaphors, no longer reveals the truth:

My temptation is quiet.

Here at life's end

Neither loose imagination,

Nor the mill of the mind

Consuming its rag and bone,

Can make the truth known.

"Now strength of body goes," he says, his requirements are modest:

Picture and book remain,

An acre of green grass

For air and exercise ([4], p. 419)

In the past his mind had consumed "rag and bone," the base ingredients of everyday life, and produced from them "high talk," inflated metaphors which he likens to poetic images parading, perhaps somewhat ostentatiously, on stilts (in "High Talk," he professes that "Processions that lack high stilts have nothing that catches the eye" ([4], p. 467)). However, in "The Circus Animals' Desertion"—-one of his last poems — "Those stilted boys," his "circus animals," have deserted him and he can do nothing but "enumerate old themes." But, in recounting the poetry of his youth and middle age, Yeats feels a certain detachment and comes to see that his art had been something of a pretence:

Players and painted stage took all my love,

And not those things that they were emblems of. ([4], pp. 471-472)

Yeats is, in a sense, rejecting the high talk of his Romantic visionary poems. What endures is not the grand poetic endeavors or the clever, elaborate metaphors, but instead the ordinary, everyday rag and bone consumed in their production. Yeats must climb down from his stilts because his stilts no 
longer adequately represent the truth. The desertion, then, is very much mutual. The masterful final stanza is as close to a rejection of poetry in poetry as can be imagined:

Those masterful images because complete

Grew in pure mind, but out of what began?

A mound of refuse or the sweepings of a street,

Old kettles, old bottles, and a broken can,

Old iron, old bones, old rags, that raving slut

Who keeps the till. Now that my ladder's gone,

I must lie down where all the ladders start,

In the foul rag-and-bone shop of the heart. ([4], p. 472)

At the end of his career-indeed, at the end of his life-Yeats seems to be coming to the conclusion (ahead of Auden) that poetry makes nothing happen. There is a sense that, to use Wallace Stevens's phrase, "A fantastic effort has failed" ([24], p. 502). But it is wrong to see this as a rejection of poetry. It is more accurate, I would suggest, to see it as a rejection of Romanticism. The question then is: what sort of poetry is this poetry that is left in its wake?

Clearly, for this poet, the poet of rags and bones, poetry which aspires to the absolute through some grand gesture of failure is no longer viable. In its place, if we are to follow Yeats through the failure of that aesthetics of failure, comes, it seems, a poetry of the everyday, modest in its aim, spare in its execution. This would certainly fit with other notable critiques of Romanticism and other accounts of what follows Romanticism. One may, for instance, think of T.E. Hulme (1883-1917), who vehemently rejected Romanticism, calling it "spilt religion" ([25], p. 71), and whose numerous prescriptions "[a]lways [to] seek the hard, definite, personal word" ([25], p. 27) and reject Romantic vagueness and "sentimental escapes to the infinite" ([25], p. 28) position him as the key theorist of a particular, so-called neo-classical, strain of Modernism. ${ }^{4}$ As his "Lecture on Modern Poetry" attests, Hulme despaired at the "tremendous amount of hocus-pocus" spoken in regard to poetry and would aggressively chastise literary critics who "mumble of the infinite":

A reviewer writing in the Saturday Review last week spoke of poetry as the means by which the soul soared in to higher regions, and as a means of expression by which it became merged into a higher kind of reality. Well, that is the kind of statement that I utterly detest. I want to speak of verse in a plain way as I would of pigs: that is the only honest way. ([25], p. 59)

Unsurprisingly, he rejected Yeats's Romantic work years before Yeats himself did:

W.B. Yeats attempts to ennoble his craft by strenuously believing in supernatural world, race-memory, magic, and saying that symbols can recall these where prose couldn't. This is an attempt to bring in an infinity again. ([25], p. 57)

Hulme based his rejection of Romanticism and his endorsement of a poetry of the everyday on what he called a "New Weltanschauung" which held "there is no such thing as an absolute truth to be discovered" ([25], p. 18), "no ultimate principles, upon which the whole of knowledge can be built

4 However, for an excellent account of Hulme's debt to Romanticism, see Frank Kermode's The Romantic Image ([26], pp. 119-137). 
once and for ever as upon a rock" ([25], p. 29), and that man, a finite being in the midst of infinite plurality — "essentially limited and incapable of anything extraordinary" ([25], p. 160) - is "only an animal, who came late" ([25], p. 19). Hulme thought that the "flat thin voice of the metaphysician" should be rejected in favor of the solidity of "clay" ([25], p. 36), "dirt" and "mud" ([25], p. 35). Transferred to poetry, this became an imprecation to try "to see things as they really are" ([25], p. 79), while understanding that "man is always man and never a god" ([25], p. 76). Hence, poetry should have "nothing to do with infinity, with mystery or with emotions," but should, instead, be "dry" and "hard" ([25], p. 79) and concern itself only with describing "solid, definite things" ([25], p. 39). "The great aim is accurate, precise and definite description," writes Hulme ([25], p. 78). Unlike the romantic poet, whom he positions as a promethean figure ("the romantic imagines everything is accomplished by the breaking of rules" [(25), p. 161]), the poet should, Hulme thought, learn to accept the ordinary world and stop striving for some sort of beyond. Behind his anti-Romantic bluster, then, is a rather modest recommendation: namely, that poetry should embody what he calls a "tentative and half-shy manner of looking at things" ([25], p. 64).

\section{Deep Metaphysical Shift Hinging on Poiesis}

What I want to suggest is that Hulme's and the later Yeats's rejection of Romanticism and their various gestures toward an alternative understanding of poetry signify not merely a stylistic change but a deep aesthetic and metaphysical shift. Insofar as Romanticism, understood as an aesthetics of failure, arose in response to the limitations of reflective consciousness, it might be expected that the rejection of Romanticism would serve implicitly to acknowledge the intractability of the epistemological problem it was trying to overcome. However, the post-Romantic attitude that Hulme and the later Yeats assume seems to dispel or disregard this problem. Both seem to have arrived at the same outlook: namely, that there is no absolute truth or ultimate principle to be discovered and that man is inherently limited and finite and that this is not a tragedy, it is simply the way things are and we should not waste time trying to look beyond how things are for some way of gilding the ordinary with the infinite. The type of poetry to which both seem drawn, with its emphasis on phenomenological description and its terse economical style, serves to underline further this rejection of metaphysics in favor of an acceptance of the limitations of knowledge and of the apparent truth that man is a finite being in a plurally-constituted world and that what he knows is merely what is around him, and that that is all he can know.

Poetry, then, makes nothing happen - the reconfigured philosophical landscape of which postRomanticism is an expression removes the very motivation of the Romantic idea that there is "something" to "make happen." Indeed, it might be said that the aesthetic and metaphysical shift represented by the move from Romanticism to post-Romanticism hinges precisely on the concept of "making," or, poiesis. As Heidegger (1889-1976) frequently reminds us, poiesis, for the Greeks, meant a bringing forth, a pro-duction to presence, and covered not only that which is brought forth by the artist and craftsman but also by nature. Poiesis, then, is very much an act of disclosure and drawing forth rather than a willful "making." However, this notion of poiesis seems to become distorted by the Romantic aesthetics of failure, which attempts to make pure poiesis, or autopoiesis, somehow accessible through the artwork. For Hegel, an arch-critic of Romanticism and of Schlegel's notion of 
Romantic irony in particular, the fatal flaw of Romanticism is that in trying to present a subjectivityrupturing moment of pure objectivity, the artist is in fact merely demonstrating his mastery and thus the inescapability of subjectivism. ${ }^{5}$ In other words, the quest for pure autopoiesis appears to render Romantic art indifferent to the external world which threatens to be made merely a provision of opportunities for the demonstration of the Romantic aesthetics of failure. Hegel writes:

Herewith we have arrived at the end of romantic art, at the standpoint of most recent times, the peculiarity of which we may find in the fact that the artist's subjective skill surmounts his material and its production because he is no longer dominated by the given conditions of a range of content and form already inherently determined in advance, but retains entirely within his own power and choice both the subject-matter and the way of presenting it. ([27], p. 602)

(Hiermit sind wir bei dem Schlüsse der romantischen Kunst angelangt, bei dem Standpunkte der neuesten Zeit, deren Eigentümlichkeit wir darin finden können, daß die Subjektivität des Künstlers über ihrem Stoffe und ihrer Produktion steht, indem sie nicht mehr von den gegebenen Bedingungen eines an sich selbst schon bestimmten Kreises des Inhalts wie der Form beherrscht ist, sondern sowohl den Inhalt als die Gestaltungsweise desselben ganz in ihrer Gewalt und Wahl behält. [28], p. 228)

Art, Hegel says, has "become a free instrument which the artist can wield in proportion to his subjective skill in relation to any material of whatever kind" ([27], p. 605). ${ }^{6} \mathrm{He}$ calls this art's "self-transcendence" ([27], p. 607) (“das Hinausgehen der Kunst über sich selbst” ([28], p. 235)). Insofar as the artist's subjective skill surmounts his material and its production in an attempt to render pure production in the artwork, the artist is in fact stifling pro-duction-poiesis—in favor of praxis. In this respect, as in many others, Romanticism has had a lasting effect. As Giorgio Agamben writes:

According to current opinion, all of man's doing - that of the artist and the craftsman as well as that of the workman and the politician - is praxis, that is, manifestation of a will that produces a concrete effect. ([29], p. 68)

This convergence of praxis and poiesis marks the loss of the clear distinction between the two concepts held by the Greeks and signals a move away from art as a way in which something comes forth into being (poiesis, or a way of happening) and focuses instead upon the artist's creative genius (praxis, or ability to make something happen). This move reduces artistic engagements with the external world to being merely occasions where the determinate might be dissolved in a gesture toward

5 This, of course, reduces the Romantic striving that hoped to gesture, through heroic failure, at a beyond of some kind, to a sort of subjective, wallowing self-pity that blindly endorses its impotence as its reward. In this light the Romantic artist is the famous "yearning and [...] morbid beautiful soul" that Hegel holds in such contempt ([27], p. 67). The wider sociological and, indeed, political implications of Hegel's critique of Romantic irony, though beyond the scope of this essay, are interesting. Romantic irony, for instance, on Hegel's reading of it, leads to a psychological isolation that is incompatible with community. Discussing the Romantic ironist, Hegel remarks on "this concentration of the ego into itself, for which all bonds are snapped and which can live only in the bliss of self-enjoyment" ([27], p. 66).

6 Hegel writes: "Das Gebundensein an einen besonderen Gehalt und eine nur für diesen Stoff passende Art der Darstellung ist für den heutigen Künstler etwas Vergangenes und die Kunst dadurch ein freies Instrument geworden, das er nach Maßgabe seiner subjektiven Geschicklichkeit in bezug auf jeden Inhalt, welcher Art er auch sei, gleichmäßig handhaben kann” ([28], p. 232). 
the infinite. In Heideggerian terms, the implicit attitude of Romanticism to its materials is one of enframing (Gestell) - a challenging or calling-forth that reduces everything to the status of "stock" or "standing-reserve" (Bestand) ([30], p. 17). Such an approach to the world (i.e., to everything that is) suppresses, conceals, the bringing forth of things from concealment that is poiesis ([30], p. 27)—quite ironic given that pure poiesis or autopoiesis is precisely what the Romantic aesthetics of failure hopes to bring forth from concealment in the artwork.

Insofar as post-Romanticism, in its turn to the ordinary and everyday, is a rejection of Romantic aesthetics and of the notion that poetry makes something happen in the Romantic sense, it marks a move away from praxis back to poiesis and thus away from the view of things as "standing-reserve," as mere resources which are to be used in some great poetico-philosophical vault into the beyond, and instead approaches the apparent, external world in the belief that that is the only world we can know and does so in a respectful manner that allows it and the things that constitute it to come forth. Art, poetry, in this sense, would not be a making happen but a way of happening - a letting "what is not yet present arrive in its presencing" ([30], p. 8), as Heidegger puts it. But how can art approach things-if mere things are all we have in the post-Romantic world - in this way? A further, though related question, one that we have already begun to touch upon, is in what way does this approach dispel the epistemological problem of reflection that provided the underlying motivation of Romanticism?

For Heidegger, the conditions for the development of the problem of reflection are put into place at the outset of Western metaphysics when the notion of "being" is distorted through an emphasis on Platonic forms which, in focusing attention upon that which is enduring and changeless, foregrounds the presence of beings while, simultaneously, casting letheward into oblivion the process of disclosure and emergence by means of which beings can appear to us at all. The legacy of this founding error is an emphasis on being as presence (the logos that makes things happen) at the expense of being as phusis (understood as "emerging-abiding sway" ([31], pp. 15, 106)) or An-wesen ("coming-topresence" ([31], p. 64)) - being which comes to be in a play of disclosure and concealment. Being, that is, understood as a way of happening. Heidegger characterizes this forgetting as a loss of truth, understood as aletheia, or disclosure - only to be replaced by an understanding of truth based on presence - that is, the correspondence model of adaequatio intellectus et rei. It is precisely such an outlook that allows a skilled skeptic like Descartes to conclude that without being able to think something in its full presence - as it is in itself-we have only an imperfect knowledge of it which leaves it open to doubt. This, in turn, leads to the formulation of the subject - that which, in order to maintain coherence, cannot be doubted - and the instantiation of the reflective model of consciousness. Kant's definitive limit-setting on the cognitive capacity of the reflective subject, coupled with the continuing, very un-Kantian, desire to know things as they are in themselves, results in the collapse of the Enlightenment project, the introduction of the term nihilism into philosophy for the first time [32], and sparks the development of Romanticism. Hegel, of course, saw that the overinvestment in the reflection model was a mistake but, from Heidegger's perspective, Hegel compounded earlier errors through a desire for full presence manifested in an absolute coincidence of thought and being. It was Heidegger in the twentieth century who argued that the metaphysical quest for presence was in fact irrational and based on a distorted understanding both of the Greek concept of being and of the way we engage with the world, which in its emphasis on reflection tends to sideline the pre-reflexive and physically embodied aspects of man's — or Dasein's—opening onto the world. 
Of course, this distortion of being and forgetting of aletheia closely correspond to the suppression of the disclosive, drawing-forth character of poiesis that, I have argued, took place with the development of Romanticism. It should now be clear that this was simply the inevitable aligning of poiesis with the metaphysics of presence. But what part does the post-Romantic revival of poiesis play in relation to this turn away from traditional metaphysics?

Romanticism aimed to overcome the limitations of metaphysics but tried to do so in a way that merely reaffirmed and further entrenched the system it was attempting to pass beyond - thereby suppressing the "truth" of things (where truth is understood as aletheia) through a gesture toward the "truth" of things (where truth is understood as presence). Post-Romanticism, in contrast, aims at drawing attention to the play of disclosure and concealment involved in a thing's coming to presence, allowing things which would usually pass unnoticed to stand forth in their own right so that one lingers over them, seeing them afresh — not in isolation but as a part of an interconnected web of relations, a world. This, clearly, would not be a practical "making happen" but a poietical "way of happening"the opening of a space in which something comes to be in its truth, a space of disclosure - a cave in the case of Plato, a mouth in the case of Auden.

\section{The Origin of the Work of Art}

At this point I would like to turn to Heidegger's highly influential and controversial essay, "The Origin of the Work of Art" [33]. Here, Heidegger suggests that in opening a space in which the play of revealing and concealing can come forth, there is "a happening of truth at work" in the artwork ([33], p. 35). Heidegger argues that this play, the work's disclosure, sets up a "world" and sets forth the "earth." The world is the perspective and set of relations opened by the work.

The world is not the mere collection of the countable or uncountable, familiar and unfamiliar things that are just there. But neither is it a merely imagined framework added by our representation to the sum of such given things. The world worlds, and is more fully in being than the tangible and perceptible realm in which we believe ourselves to be at home. World is never an object that stands before us and can be seen. World is the ever-nonobjective to which we are subject.... ([33], p. 43)

In contrast to this, but fundamentally connected to it, the earth is the stubborn, inexhaustible materiality of the work - it is that which resists disclosure and in so doing is brought forth as such, unconcealed as a concealing:

It shows itself only when it remains undisclosed and unexplained. Earth thus shatters every attempt to penetrate it. [...] The earth appears openly cleared as itself only when it is perceived and preserved as that which is by nature undisclosable, that which shrinks from every disclosure and constantly keeps itself closed up. [...] To set forth the earth means to bring it into the Open as the self-secluding. ([33], pp. 45-46)

The earth is the impenetrable that is brought out as such into the clearing of the work; it is that of the artwork which is inexhaustible. The work of art works by setting forth materiality in a certain unsubsumability, thereby making evident the resistance that the thingly element of the thing must offer if it is to emerge in its own aspect, disclosed in its coming to presence. Thus, for Heidegger - and, I am suggesting, possibly for post-Romanticism too-the work of art is a setting forth of materiality in its self-concealing unsubsumability: the earth is brought forth from the oblivion of the everyday into the 
open space of the work, not to be subsumed by another form but to disclose its impenetrability. As such, the earth of the artwork is never "used up," no single understanding, view or interpretation is completely adequate to it and so as long as the work works it can never simply be fixed in a particular understanding. Heidegger makes this point thus:

The self-seclusion of earth [...] is not a uniform, inflexible staying under cover, but unfolds itself in an inexhaustible variety of simple modes and shapes. To be sure, the sculptor uses stone just as the mason uses it, in his own way. But he does not use it up. That happens in a certain way only where the work miscarries. To be sure, the painter also uses pigment, but in such a way that colour is not used up but rather only now comes to shine forth. To be sure, the poet also uses the word - not, however, like ordinary speakers and writers who have to use them up, but rather in such a way that the word only now becomes and remains truly a word. ([33], p. 46)

This notion that "earth" comes forth unfolded in an inexhaustible number of ways, and so can never be finally pinned down by a single interpretation or understanding, has received attention from a number of commentators on Heidegger. J.M. Bernstein, for instance, remarks: "[A]lthough capable of being set forth in an endless variety of ways, the earth itself cannot be finally, once and for all, revealed" ([34], p. 119); similarly, Kai Hammermeister writes: "Because all art contains this moment of earth, no one will ever come to terms with the work; no single interpretation will ever suffice" ([35], p. 182). For Heidegger, then, the more a work withstands interpretation, the more the earth asserts itself ("juts through the world" ([33], pp. 54, 61, 67)), as Heidegger is wont to put it) as impenetrable and self-closing. Of course, at the same time, the more the earthly aspect of the work resists any single interpretation, the more open the work becomes. That is to say, the more the self-closing earthly characteristic of the work asserts itself, the more the world of the work is exercised in striving to open the work altogether (the paradox being that if it were to succeed the work would cease to work and so would be finally closed and altogether without a world). In Heidegger's words, "The world, in resting upon the earth, strives to surmount it. As self-opening it cannot endure anything closed. The earth, however, as sheltering and concealing, tends always to draw the world into itself and keep it there" ([33], p. 47). So the two parts of the work strive against one another forming the work-being of the work: the world moves to open the work up whilst the earth strives to close it. The more the world strives, opening up various relations and perspectives, the more open the work appears and, yet, the more it actually resists opening, resists any final interpretation or understanding; thus, it can be said, the more the earth is set forth, the more the world worlds, and vice versa. Heidegger places considerable emphasis on this mutual intensification and interdependence:

In the struggle, each opponent carries the other beyond itself. Thus the striving becomes ever more intense as striving, and more authentically what it is. The more the struggle overdoes itself on its own part, the more inflexibly do the opponents let themselves go into the intimacy of simple belonging to one another. The earth cannot dispense with the Open of the world if it itself is to appear as earth in the liberated surge of its self-seclusion. The world, again, cannot soar out of the earth's sight if, as the governing breadth and path of all essential destiny, it is to ground itself on a resolute foundation. ([33], p. 48)

Later in the essay, he writes: "[A]s a world opens itself the earth comes to rise up. It stands forth as that which bears all, as that which is sheltered in its own law and always wrapped up in itself" ([33], 
p. 61); and, again: "The nature of the earth, in its free and unhurried bearing and self-closure, reveals itself [...] only in the earth's jutting into a world, in the opposition of the two" ([33], p. 67). The importance, for Heidegger, of this interplay of revealing and concealing - that is, the operation of disclosure - is affirmed by Gadamer who suggests that the "universal thesis of Heidegger's philosophy" is that "beings hold themselves back by coming forward into the openness of presence" ([36], p. 227). For Heidegger, the great artwork is the "figure" (Gestalt) ([33], p. 62) which fixes in place this open, dynamic striving of world and earth at its most intense. Heidegger writes: "In the earth, [...] as essentially self-closing, the openness of the Open finds the greatest resistance (to the Open) and thereby the site of the Open's constant stand, where the figure must be fixed in place"; and, again: "This conflict is fixed in place in the figure of the work and becomes manifest by it" ([33], p. 67). It is as such a striving, by opening a world and by maintaining that world in the self-concealing resistance of earth, Heidegger claims, that the great artwork "first gives to things their look and to men their outlook on themselves" ([33], p. 42).

This agonistic performance of concealing and revealing that constitutes the work-being of the work is, Heidegger argues, the happening of aletheia or truth. As Heidegger puts it, "Setting up a world and setting forth the earth, the work is the fighting of the battle in which the unconcealedness of beings as a whole, or truth, is won" ([33], p. 54); and, "Truth establishes itself in the work. Truth is present only as the conflict between lighting and concealing in the opposition of world and earth" ([33], p. 60). Art projects the opening in which beings show themselves in their coming to presence. Art, in other words, is the clearing in which disclosure-aletheia-happens. As such, Heidegger suggests, all art is "essentially poetry" ([33], p. 70) — that is, poiesis - insofar as poetry is the projective "saying of the unconcealedness of what is" ([33], p. 71). It is on these grounds that Heidegger can state: "Art then is the becoming and happening of truth" ([33], p. 69), or "Art is the setting-into-work of truth" ([33], p. 74).

Post-Romanticism, I am suggesting, would follow this Heideggerian attention to poiesis as worlddisclosure - not reaching beyond to some imagined absolute out of a sense of the incompleteness of our knowledge of the world around us but attending to the ordinary and the everyday in the realization that any perceived lack of presence is part of the play of concealment and disclosure at work in a thing's coming to presence, its coming forth or poiesis (whether that be the poiesis of the artist, craftsman, or nature).

\section{Pessoa's Post-Romanticism}

What would post-Romantic poetry look like? To try to answer this question we now turn to the Portuguese poet Fernando Pessoa. What is most remarkable about Pessoa-whose name means "person" in Portuguese - is that he divided himself up into a number of literary alter egos which he referred to as "heteronyms." Besides himself, Fernando Pessoa (who remained a distinct figure included in the imaginary world of the heteronyms), there is Alberto Caeiro, Ricardo Reis and Álvaro de Campos, each of whom can be regarded as an important "poet" in his own right. Richard Zenith gives an idea of the power and scope of Pessoa's world-creating imagination:

In addition to the three full-fledged heteronyms, the mature Pessoa gave birth to Bernardo Soares, a "semiheteronym" who authored the sprawling fictional diary known as The Book of Disquietude; António Mora, a prolific philosopher and sociologist; the Baron of Teive, an essayist; Thomas Crosse, whose critical 
writings in English promoted Portuguese literature in general and Alberto Caeiro's work in particular; I.I. Crosse, Thomas's brother and collaborator; Coelho Pacheco, a poet; Raphael Baldaya, astrologer; Maria José, a nineteen-year-old hunchback consumptive who wrote a desperate, unmailed love letter to a handsome metalworker who passed under her window on his way to work each day; and so on, and so on, and so on. At least seventy-two names besides Fernando Pessoa were "responsible" for the thousands of texts that were actually written and the many more that he only planned, and other names will probable turn up as scholars continue to explore the still not completely charted territory of his writings. ([37], p. 5)

Indeed, a trunk containing 27,500 manuscripts and fragments was discovered following Pessoa's death - only 5,000 of these have so far been published ([38], pp. 109-110). Commenting on the main heteronyms, Harold Bloom writes: "Two of them-Caeiro and Campos - are great poets, wholly different from each other and from Pessoa, not to mention Reis, who is an interesting minor poet" ([39], p. 485). It is to these two poets that we shall now turn to try to understand further what post-Romanticism might be.

\section{1. Álvaro de Campos}

Campos's poem "The Tobacco Shop" ([37], pp. 173-179) ("Tabacaria” [40]), is exemplary in the way it demonstrates the emergence or coming-to-be of a certain post-Romanticism in the midst of Romanticism's and philosophy's failure. The world of the poem's protagonist is one of existential angst caused by the failure of reflection which has left the world riven in two, a subjective world of inaction and paranoiac metaphysical musing on the one side and the real, objective world of action and immediacy on the other. Trapped in the former, the protagonist considers the wasted potential of his life, unable, as he is, to break free from the endless, empty reflection which keeps him from the "real," concrete world in which he might find fulfillment, a world for which he longs but in relation to which he feels utterly alienated. This divided world is represented to him by the two sides of the street where he lives and which he observes from the window of his room. He feels no less detached from the street itself, which in uniting its two sides (and here one might think of Auden's "valley") seems mysterious, as does the fact that other people appear able to cross the street without difficulty, living their lives as though the world were not divided between the subjectivity to which reflection appears to condemn one, and the outside, objective world of the real. The poem begins:

I'm nothing.

I'll always be nothing.

I can't want to be something.

But I have in me all the dreams of the world.

Windows of my room,

The room of one of the world's millions nobody knows

(And if they knew me, what would they know?),

You open onto the mystery of a street continually crossed by people,

A street inaccessible to any and every thought,

Real, impossibly real, certain, unknowingly certain,

With the mystery of things beneath the stones and beings, 
With death making the walls damp and the hair of men white,

With Destiny driving the wagon of everything down the road of nothing.

Today I'm defeated, as if I'd learned the truth.

Today I'm lucid, as if I were about to die

And had no greater kinship with things

Than to say farewell, this building and this side of the street becoming

A row of train cars, with the whistle for departure

Blowing in my head

And my nerves jolting and bones creaking as we pull out.

(Não sou nada.

Nunca serei nada.

Não posso querer ser nada.

À parte isso, tenho em mim todos os sonhos do mundo.

Janelas do meu quarto,

Do meu quarto de um dos milhões do mundo que ninguém sabe quem é

(E se soubessem quem é, o que saberiam?),

Dais para o mistério de uma rua cruzada constantemente por gente,

Para uma rua inacessível a todos os pensamentos,

Real, impossivelmente real, certa, desconhecidamente certa,

Com o mistério das coisas por baixo das pedras e dos seres,

Com a morte a pôr humidade nas paredes e cabelos brancos nos homens,

Com o Destino a conduzir a carroça de tudo pela estrada de nada.

Estou hoje vencido, como se soubesse a verdade.

Estou hoje lúcido, como se estivesse para morrer,

E não tivesse mais irmandade com as coisas

Senão uma despedida, tornando-se esta casa e este lado da rua

A fileira de carruagens de um comboio, e uma partida apitada

De dentro da minha cabeça,

E uma sacudidela dos meus nervos e um ranger de ossos na ida.)

The focal point of the other side of the street's reality, the foil to the protagonist's subjectivism is the tobacco shop:

Today I'm bewildered, like a man who wondered and discovered and forgot.

Today I'm torn between the loyalty I owe

To the outward reality of the Tobacco Shop across the street

And to the inward reality of my feeling that everything's a dream.

(Estou hoje perplexo, como quem pensou e achou e esqueceu.

Estou hoje dividido entre a lealdade que devo

À Tabacaria do outro lado da rua, como coisa real por fora,

E à sensação de que tudo é sonho, como coisa real por dentro.)

The protagonist allows his sense of failure and restless dissatisfaction to unfold: 
I failed in everything.

Since I had no ambition, perhaps I failed in nothing.

I left the education I was given,

Climbing down from the window at the back of the house.

I went to the country with big plans.

But all I found was grass and trees,

And when there were people they were just like others.

I step back from the window and sit in a chair. What should I think about?

(Falhei em tudo.

Como não fiz propósito nenhum, talvez tudo fosse nada.

A aprendizagem que me deram,

Desci dela pela janela das traseiras da casa.

Fui até ao campo com grandes propósitos.

Mas lá encontrei só ervas e árvores,

E quando havia gente era igual à outra.

Saio da janela, sento-me numa cadeira. Em que hei-de pensar?)

Bewildered by the inaccessible reality of the street below, his thoughts are driven further inward, leaving him yet more paralyzed by reflection and anguished over the impotence and complete fruitlessness of his potential in actuality: "How should I know what I'll be, I who don't know what I am? / Be what I think? But I think of being so many things! / And there are so many who think of being the same thing that we can't all be it!" ("Que sei eu do que serei, eu que não sei o que sou? / Ser o que penso? Mas penso tanta coisa! / E há tantos que pensam ser a mesma coisa que não pode haver tantos!"). He-"We", he says-“conquered the whole world before getting out of bed" ("Conquistamos todo o mundo antes de nos levantar da cama"), but, in fact, he is destined to utter ineffectuality, destined to sing "the song of the Infinite in a chicken coop" ("a cantiga do Infinito numa capoeira"):

But I am, and perhaps will always be, the man in the garret,

Even though I don't live in one.

I'll always be the one who wasn't born for that;

I'll always be merely the one who had qualities;

I'll always be the one who waited for a door to open in a wall without doors

And sang the song of the Infinite in a chicken coop

And heard the voice of God in a covered well.

Believe in me? No, not in anything.

(Mas sou, e talvez serei sempre, o da mansarda,

Ainda que não more nela;

Serei sempre o que não nasceu para isso;

Serei sempre só o que tinha qualidades;

Serei sempre o que esperou que lhe abrissem a porta ao pé de uma parede sem porta,

E cantou a cantiga do Infinito numa capoeira,

E ouviu a voz de Deus num poço tapado. 
Crer em mim? Não, nem em nada.)

He longs to be free from this unreal shadow-world and cured of feverish speculation and so makes an appeal to nature, to the outside world from which he is disconnected: "Let Nature pour over my seething head / Its sun, its rain, and the wind that finds my hair, / And let the rest come if it will or must, or let it not come" ("Derrame-me a Natureza sobre a cabeça ardent / O seu sol, a sua chuva, o vento que me acha o cabelo, / E o resto que venha se vier, ou tiver que vir, ou não venha"). He looks for consolation in the poetry that arrives out of his failed connection with the world, but appears to set little store by such an aesthetics of failure: "But at least, from my bitterness over what I'll never be, / There remains the hasty writing of these verses, / A broken gateway to the Impossible" ("Mas ao menos fica da amargura do que nunca serei / A caligrafia rápida destes versos, / Pórtico partido para o Impossível"). He is caught in the classic bind of reflection's limitations: he cannot rise above his subjective position to account for the objective and so turns inward, but in objectivizing the self, by setting it up on the stage of the mind, the self too falls foul of the dualistic split of reflection and so even self-certainty appears denied. He writes: "I invoke / My own self and find nothing" ("invoco / A mim mesmo e não encontro nada"). Thus, the external, objective world from which he feels utterly separate nevertheless oppresses him with a force both as powerful and as reflectively ungraspable as that of his inner world:

([...] I go to the window and see the street with absolute clarity.

I see the shops, I see the sidewalks, I see the passing cars,

I see the clothed living beings who pass each other.

I see the dogs that also exist,

And all of this weighs on me like a sentence of exile,

And all of this is foreign, like everything else.)

$(([\ldots]$ Chego à janela e vejo a rua com uma nitidez absoluta.

Vejo as lojas, vejo os passeios, vejo os carros que passam,

Vejo os entes vivos vestidos que se cruzam,

Vejo os cães que também existem,

E tudo isto me pesa como uma condenação ao degredo,

E tudo isto é estrangeiro, como tudo.))

His fascination with the - to him-impenetrable world of the other side of the street, which is essentially a fascination with the limitations of reflection, prevents him from valuing the poetry he has written expressive of his unreflective awareness of existence:

Musical essence of my useless verses,

If only I could look at you as something I had made

Instead of always looking at the Tobacco Shop across the street,

Trampling on my consciousness of existing,

Like a rug a drunkard stumbles on

Or a doormat stolen by gypsies and it's not worth a thing.

(Essência musical dos meus versos inúteis,

Quem me dera encontrar-te como coisa que eu fizesse, 
E não ficasse sempre defronte da Tabacaria de defronte,

Calcando aos pés a consciência de estar existindo,

Como um tapete em que um bêbado tropeça

Ou um capacho que os ciganos roubaram e não valia nada.)

It is at this point that the owner of the tobacco shop enters the poem. If the other side of the street represents the outer, objective world to which the protagonist is denied access, and the tobacco shop is the symbolic centre of that world, then the owner of the shop is the lord of that world. ${ }^{7}$ There is a sense in which this appearance is presented as a quasi-religious revelation-the tobacco shop is the impenetrable beyond (a temple, perhaps?), yet now the lord of the tobacco shop comes forth and shows himself. But there is nothing divine about this decidedly post-Romantic lord of the commonplace who will someday die and be forgotten:

But the Tobacco Shop Owner has come to the door and is standing there.

I look at him with the discomfort of a half-twisted neck

Compounded by the discomfort of a half-grasping soul.

He will die and I will die.

He'll leave his signboard, I'll leave my poems.

Eventually the street where the sign was will die,

And so will the language in which my poems were written.

Then the whirling planet where all of this happened will die.

On other planets of other solar systems something like people

Will continue to make things like poems and to live under things like signs,

Always one thing facing the other,

Always one thing as useless as the other,

Always the impossible as stupid as reality,

Always the inner mystery as true as the mystery sleeping on the surface.

Always this thing or always that, or neither one thing nor the other.

(Mas o Dono da Tabacaria chegou à porta e ficou à porta.

Olho-o com o desconforto da cabeça mal voltada

E com o desconforto da alma mal-entendendo.

Ele morrerá e eu morrerei.

Ele deixará a tabuleta, eu deixarei os versos.

A certa altura morrerá a tabuleta também, e os versos também.

Depois de certa altura morrerá a rua onde esteve a tabuleta,

E a língua em que foram escritos os versos.

Morrerá depois o planeta girante em que tudo isto se deu.

Em outros satélites de outros sistemas, qualquer coisa como gente

Continuará fazendo coisas como versos e vivendo por baixo de coisas como tabuletas.

7 This is implied in the translation of Dono (in Dono da Tabaccaria) as "Owner." In English, "lord" is a now archaic meaning of "owner." Similarly, in Portuguese, Dono can mean both "owner" and "lord" (indeed, Jonathan Griffin translates the word as lord in the Penguin edition of Pessoa's Selected Poems [41]. 
Sempre uma coisa defronte da outra,

Sempre uma coisa tão inútil como a outra,

Sempre o impossível tão estúpido como o real,

Sempre o mistério do fundo tão certo como o sono de mistério da superfície,

Sempre isto ou sempre outra coisa ou nem uma coisa nem outra.)

Next, in what marks a significant turning point in the poem, the reality of the street intrudes, interrupting his speculations. Crucially, the street is no longer "impossibly real" but mere plausible reality, not something that stands absolutely apart, but belonging to a world to which the protagonist, despite his reflective alienation, also belongs but which has so far gone unnoticed, concealed in the oblivion of the everyday. This plausible reality, no longer caught in the diremption of subject and object, is disclosed by the simplest, most mundane act:

But a man has entered the Tobacco Shop (to buy tobacco?),

And plausible reality suddenly hits me.

I half rise from my chair-energetic, convinced, human-

And will try to write these verses in which I say the opposite.

(Mas um homem entrou na Tabacaria (para comprar tabaco?),

E a realidade plausível cai de repente em cima de mim.

Semiergo-me enérgico, convencido, humano,

E vou tencionar escrever estes versos em que digo o contrário.)

The disclosure of this tangible world - this world where the street is merely a street and the tobacco shop is merely a tobacco shop, in a town that people believe and die in - is a truth-event which positions the protagonist despite himself. This irruption of the world awakens a calming sensuousness which frees him from his anxious and now seemingly misbegotten reflections on his inexorable paralysis in the face of an apparently insurmountable dualism. This, very clearly, is a move from truth understood as correctness - where the world did not make sense and seemed strange because it did not correctly match up to his idea of how it should be - to truth understood as aletheia. Now, "energetic, convinced, human," his verses of longing and failure seem unimportant and lacking in truth:

I light up a cigarette as I think about writing them,

And in that cigarette I savour a freedom from all thought.

My eyes follow the smoke as if it were my own trail

And I enjoy, for a sensitive and fitting moment,

A liberation from all speculation

And an awareness that metaphysics is a consequence of not feeling very well.

Then I lean back in the chair

And keep smoking.

As long as Destiny permits, I'll keep smoking.

(Acendo um cigarro ao pensar em escrevê-los

E saboreio no cigarro a libertação de todos os pensamentos.

Sigo o fumo como uma rota própria,

E gozo, num momento sensitivo e competente, 
A libertação de todas as especulações

E a consciência de que a metafísica é uma consequência de estar mal disposto.

Depois deito-me para trás na cadeira

E continuo fumando.

Enquanto o Destino mo conceder, continuarei fumando.)

Relieved of the condition of failure, his thoughts turn, briefly, affirmatively, to the street life of which he now finds himself a part, the tobacconist's having given to things their look and, to the protagonist of the poem, his outlook on himself ([33], p. 42): “(If I married my washwoman's daughter / Perhaps I would be happy.) / I get up from the chair. I go to the window" ("(Se eu casasse com a filha da minha lavadeira / Talvez fosse feliz.) / Visto isto, levanto-me da cadeira. Vou à janela"). His postRomantic awakening and acceptance of the mere-ness of the ordinary in all its disclosive truth culminates as the poem reaches its conclusion. He finds himself utterly immersed unreflectively in the world - the world as it is, without ideals or hopes:

The man has come out of the Tobacco Shop (putting change into his pocket?).

Ah, I know him: it's unmetaphysical Esteves.

(The Tobacco Shop Owner has come to the door.)

As if by divine instinct, Esteves turns around and sees me.

He waves hello, I shout back "Hello, Esteves!" and the universe

Falls back into place without ideals or hopes, and the Owner of the Tobacco Shop smiles.

(Ah, conheço-o: é o Esteves sem metafísica.

(O Dono da Tabacaria chegou à porta.)

Como por um instinto divino o Esteves voltou-se e viu-me.

Acenou-me adeus, gritei-lhe Adeus ó Esteves!, e o universo

Reconstruiu-se-me sem ideal nem esperança, e o Dono da Tabacaria sorriu.)

This poem presents itself as eminently post-Romantic. It signals a clear rejection of the romantic aesthetics of failure but it also, contra Hegel, rejects the possibility of a philosophical overcoming of the limitations of reflection and concludes with an affirmation of the everyday. That the everyday world is disclosed in its truth, and as truth, by means of its poetic projection, seems to support Heidegger's belief in art's truth-bearing power as well as suggesting that art can, once again, constitute the most eminent means by which, as Hegel put it, "truth fashions an existence for itself" ([27], p. 103). ${ }^{8}$

As may be gleaned from the dénouement of "The Tobacco Shop," Campos believed the antidote to fruitless, empty metaphysical speculation lay in a particular recognition of the sensuous world. In fact, Pessoa positions Campos as a major figure in a literary movement called Sensationism and as being motivated by a desire "To feel everything in every way" ([37], p. 146). In his explosive SensationistFuturist manifesto, "Ultimatum," Campos rails against the modern world, including key contemporary literary figures. Of Yeats, he writes: "Get out, Yeats of the Celtic brume wafting around a sign pointing nowhere, sackful of flotsam that washed up on the shore of shipwrecked English symbolism!" ([43], p. 73). He calls on the "posthumous Romanticism of liberalists far and wide" to

8 Hegel himself, of course, could not envisage any such prospect: "Uns gilt die Kunst nicht mehr als die höchste Weise, in welcher die Wahrheit sich Existenz verschafft" ([42], p. 132). 
"[p]ass by" ([43], p. 77) and yet bemoans the fact that there is "[n]ot one literary movement that's so much as the noonday shadow of Romanticism!" ([43], p. 75). Giving an account of Sensationism, Pessoa wrote: "To feel is to create. [...] Feeling is thinking without ideas, hence understanding, since the Universe has no ideas," and, very apposite in light of "The Tobacco Shop," "Feeling opens the doors of the prison where thought confines the soul" ([43], pp. 66, 68). The message is clear: "To feel is to understand. To think is to err" ([43], p. 67). However, with regard to Sensationism, Campos was merely a follower-Caeiro was the master. Up until meeting Caeiro, Campos had, by his "own" admission, written very little_- "three sonnets and two poems" which, he says, reveal him to have been "helplessly adrift." He was "a nervous machine that busily did nothing," but, he writes, "As soon as I met Caeiro, I found my true self" ([43], p. 49). So to understand the inspiration for Campos's postRomanticism we must now, in conclusion, look at the work of Caeiro.

\subsection{Alberto Caeiro}

Caeiro's poetry is bucolic and tends respectfully to things as they appear to his senses, believingas a simple matter of fact - that that is all there is. He disavows reflection, judging it to distort the world around us and our primarily unreflective, embedded position in it: "We live before we philosophise, we exist before we know we do, / And the earlier fact merits at least homage and precedence" ([44], p. 68) ("Vivemos antes de filosofar, existimos antes de o sabermos, / E o primeiro fato merece ao menos a precedência e o culto" [45]). He suggests that "to think is to not understand" ([37], p. 48) ("pensar é não compreender" [46]) and states that he would only think about the world if he "weren’t well" ([37], p. 49) ("Se eu adoecesse pensaria nisso" [46]). As if by way of explanation, he offers: "I have no philosophy, I have senses" ([37], p. 48) ("Eu não tenho filosofia: tenho sentidos..." [46]). Caeiro would surely agree with Raymond Geuss's summary of Heidegger's later opinion: "[T]o do philosophy at all, particularly transcendental philosophy, is to show that one is living in error about what it is to be human" ([47], p. 58; [48]).

In Campos's "The Tobacco Shop" we see the protagonist's move from implicitly understanding truth as adequatio - an understanding which rendered his world disjointed - to an implicit understanding of truth as aletheia, which allowed the world to rebuild itself, poietically, around him. Caeiro's rejection of reflection is even more complete. He sees things as they stand in themselves, in their poietic coming-to-presence, without any comprehension of how things could be at all different. Thus, the notion of aletheia, which still implies a sort of presentation or placing-in-view, would make little sense to him ([49], p. 16). His opening onto the world is wholly sensuous - he is restricted to the surfaces his senses encounter, not allowing any reflective distance between himself and the world that surrounds him [38]. This is "sense" as understood by Jean-Luc Nancy (1940-), who writes:

If sense is, in a sense, still manifest insofar as it is the patency or openness [apérité] of the world, it is nonetheless not manifest in the mode of a placing-in-view or placing-in-the-light on a scene, display, or monstrance. The opening that it is or that it makes is not frontal: it is a passage through a narrow pass, praes-entia. ([49], p. 16)

Thus, in his "Translator's Preface to the Poems of Alberto Caeiro," Thomas Crosse (a translator and essayist - fictitious, of course) refers to Caeiro as "the pure and absolute Sensationist who bows down 
to sensations qua exterior and admits no more" ([43], p. 53), while Campos is merely "the undisciplined child of sensation" ([43], p. 54). For Caeiro, as for Campos, "[s]ensation is all...and thought is a disease," but for Caeiro sensation means "the sensation of things as they are" in contrast to Campos's unrestrained desire to feel all things in all ways ([43], p. 54). And the way things are, for Caeiro, is simply the way they appear to the senses without any artificially imported significance, mystery or Romantic embellishment. Poem 10 of his collection The Keeper of Sheep makes clear his rejection of what he considers to be the falsity of Romanticism:

"Hello, keeper of sheep

There on the side of the road.

What does the blowing wind say to you?"

"That it's wind and that it blows,

And that it has blown before,

And that it will blow hereafter.

And what does it say to you?"

"Much more than that.

It speaks to me of many other things:

Of memories and nostalgias,

And of things that never were."

"You've never heard the wind blow.

The wind only speaks of the wind.

What you heard was a lie,

And the lie is in you." ([37], p. 53)

(“Olá, guardador de rebanhos,

Aí à beira da estrada,

Que te diz o vento que passa?"

"Que é vento, e que passa,

E que já passou antes,

E que passará depois.

E a ti o que te diz?"

"Muita cousa mais do que isso.

Fala-me de muitas outras cousas.

De memórias e de saudades

E de cousas que nunca foram."

"Nunca ouviste passar o vento.

$\mathrm{O}$ vento só fala do vento.

$\mathrm{O}$ que lhe ouviste foi mentira,

E a mentira está em ti." [46]) 
Despite what certain mystically-inclined poets might believe, "the stars are just stars / And the flowers just flowers, / Which is why we call them stars and flowers" ([37], p. 57) ("as estrelas não são senão estrelas / Nem as flores senão flores. / Sendo por isso que lhes chamamos estrelas e flores" [46]). "Mystic poets" (“Os poetas místicos”), Caeiro writes, "are sick philosophers" ("são filósofos doentes") (damning indeed considering his view that "philosophers are lunatics" ("os filósofos são homens doidos")!). He continues:

Because mystic poets say that flowers feel

And that stones have souls

And that rivers are filled with rapture in the moonlight.

But flowers, if they felt, wouldn't be flowers,

They would be people;

And if stones had souls, they would be living things, not stones;

And if rivers were filled with rapture in the moonlight,

Those rivers would be sick people. ([44], p. 31)

(Porque os poetas místicos dizem que as flores sentem

E dizem que as pedras têm alma

E que os rios têm êxtases ao luar.

Mas flores, se sentissem, não eram flores,

Eram gente;

E se as pedras tivessem alma, eram cousas vivas, não eram pedras;

E se os rios tivessem êxtases ao luar,

Os rios seriam homens doentes. [45])

Talk of the mystery of things is incomprehensible to Caeiro: "The mystery of things? What mystery? / The only mystery is that some people think about mystery" ([37], p. 49) ("O mistério das cousas? Sei lá o que é mistério! / O único mistério é haver quem pense no mistério" [46]). In poem 39 of The Keeper of Sheep, Caeiro forcefully sets forth this view:

The mystery of things-where is it?

Why doesn't it come out

To show us at least that it's mystery?

What do the river and the tree know about it?

And what do I, who am no more than they, know about it?

Whenever I look at things and think about what people think of them,

I laugh like a brook cleanly plashing against a rock.

For the only hidden meaning of things

Is that they have no hidden meaning.

It's the strangest thing of all,

Stranger than all poets' dreams

And all philosophers' thoughts,

That things are really what they seem to be 
And there's nothing to understand.

Yes, this is what my senses learned on their own:

Things have no meaning; they exist.

Things are the only hidden meaning of things. ([37], p. 62)

(O mistério das cousas, onde está ele?

Onde está ele que não aparece

Pelo menos a mostrar-nos que é mistério?

Que sabe o rio disso e que sabe a árvore?

E eu, que não sou mais do que eles, que sei disso?

Sempre que olho para as cousas e penso no que os homens pensam delas,

Rio como um regato que soa fresco numa pedra.

Porque o único sentido oculto das cousas

É elas não terem sentido oculto nenhum,

É mais estranho do que todas as estranhezas

$E$ do que os sonhos de todos os poetas

E os pensamentos de todos os filósofos,

Que as cousas sejam realmente o que parecem ser

E não haja nada que compreender.

Sim, eis o que os meus sentidos aprenderam sozinhos:-

As cousas não têm significação: têm existência.

As cousas são o único sentido oculto das cousas. [46])

What Caeiro teaches, then, is to see things as they are, as they stand in themselves, rather than, metaphysically, according to some preconceived idea or, romantically, according to some imagined sense of a resonant, mythical beyond:

What we see of things are the things.

Why would we see one thing when another thing is there?

Why would seeing and hearing be to delude ourselves

When seeing and hearing are seeing and hearing?

What matters is to know how to see,

To know how to see without thinking,

To know how to see when seeing

And not think when seeing

Nor see when thinking. ([37], p. 57)

(O que nós vemos das cousas são as cousas.

Por que veríamos nós uma cousa se houvesse outra?

Por que é que ver e ouvir seria iludirmo-nos

Se ver e ouvir são ver e ouvir?

O essencial é saber ver, 
Saber ver sem estar a pensar,

Saber ver quando se vê,

E nem pensar quando se vê

Nem ver quando se pensa. [46])

Forgoing the reflective attitude and learning to see things as they are is not a simple task. To cultivate one's unreflective comportment to the world - "To know how to see without thinking" —one must submit oneself to what Caeiro calls "Lessons in unlearning" ([37], p. 57) ("Uma aprendizagem de desaprender" [46]). ${ }^{9}$ Caeiro calls this "the only mission in the world": "To exist clearly, / And to do so without thinking about it" ([37], p. 59) (“existir claramente, / E saber faze-lo sem pensar nisso" [46]).

For Caeiro, to dwell thus is to dwell poetically. Things are not simply objects, present and unchanging, thrown before us. In Caeiro's naturally projective, poietic gaze (which he describes as "clear like a sunflower" ("nítido como um girasol")), the world is remade anew in an endless coming — or birth — to presence. Thus, he writes:

And what I see at each moment

Is what I never saw before,

And I'm very good at noticing things.

I'm capable of having that sheer wonder

That a newborn child would have

If he realised he'd just been born.

I always feel that I've just been born

Into an endlessly new world. ([37], p. 48)

(E o que vejo a cada momento

É aquilo que nunca antes eu tinha visto,

E eu sei dar por isso muito bem...

Sei ter o pasmo essencial

Que tem uma criança se, ao nascer,

Reparasse que nascera deveras...

Sinto-me nascido a cada momento

Para a eterna novidade do Mundo... [46])

To be always in statu nascendi in this way is to occupy the sensuous littoral of consciousness, withstanding thought's propensity toward illusory self-aggrandizement which, as we have seen, ends with dualism and the threat of skepticism in a nihilistic awareness of its own limitations. To hold such a position is to accede to what Nancy calls the "poverty of thought," suggesting that "[it] is this poverty that we must think. Thought is this: merely to be born to presence, and not to represent its presentation or its absentation" ([51], p. 4).

This is how Caeiro lives - in the sensuous poverty of thought — and it is why he can say things such as: "The astonishing reality of things / Is my discovery every day" ([44], p. 58) ("A espantosa

9 Lessons such that we would become what Ricardo Reis calls “Thoughtlessly wise” ([41], p. 91) (“Sábios incautos” [50]). 
realidade das cousas / É a minha descoberta de todos os dias" [45]). For Nancy, this birth to presence is signaled by the "there is" of reflection which speaks the meagerness of thought's poverty:

Before all representational grasp, before a consciousness and its subject, before science, and theology, and philosophy, there is that: the that of, precisely, there is. But "there is" is not itself a presence, to which our signs, our demonstrations, and our monstrations might refer. One cannot "refer" to it or "return" to it: it is always, already, there, but neither in the mode of "being" (as a substance) nor that of "there" (as a presence). It is there in the mode of being born.... ([51], p. 4)

The imperative, then, is to "leave behind all our determining, identifying, destining thoughts" - to undergo what Caeiro calls lessons in unlearning. As Nancy points out, this amounts to leaving behind "what 'thinking' usually means" ([51], p. 174). But thinking can only mean what it usually means because there is, first of all, some thing to think:

At the heart of thought, there is some thing that defies all appropriation by thought (for example, its appropriation as "concept," or as "idea," as "philosophy" or as "meditation," or even as "thought"). This thing is nothing other than the immanent immobility of the fact that there are things. ([51], p. 169)

This is what is recognized in the poverty of the "there is," namely that at the basis of reflective thought, both resisting it and enabling it, there are things and it is in this fact that indigent thought and thing are united in the sensuousness of the birth to presence. Nancy comments that in this "initial and ultimate point of thought, thought cannot be anything other than the thing in its presence. Which, strictly speaking, would mean thought without reflexivity, without intentionality, without 'adequatio rei et intellectus.' For the there is (some thing) is the point where thing becomes thought and thought becomes thing" ([51], p. 169).

Caeiro, the pure Sensationist, is somehow able to inhabit this moment (it is, we might say, Caeiro's kairos) in which sense understood as signification and sense understood as sensation are unified in the birth-to-presence of the world. ${ }^{10}$ Beneath reflection, at the point of thought's most abject poverty, Caeiro reaches the heart of things ([51], pp. 167-188). Caeiro's verse announces the failure of philosophy and Romanticism by presenting them as simply mistaken ways of relating to the world. In this regard he might be thought of as a natural Nietzschean. ${ }^{11}$ He sings of the mereness of things and their astonishing plainness and in this way he serves as witness to the immediacy and obviousness of the world. For these reasons his work is certainly post-Romantic and it presents poetry as being able to speak effectively the plain reality of things in a way that philosophy cannot. Furthermore, in Caeiro's unreflective, projective gaze the world is disclosed in an endless, poietic coming to presence that resists thought as it is usually understood but does not result in dualism because it marks thought's unreflective joining with the world in sense - a joining which, therefore, is at one and the same time man's finitude and his inseparability from the world. It is in this sense that post-Romanticism, with its sensitivity to poiesis, would consider the artwork not an expression of the will of the artist-creator or as some sort of appearance of the sublime, but simply as a way in which the "there is" happens. For, as

10 This joining of signification and sensation in the sense of things is also alluded to in a line by Reis: "I stick to facts. Just what I feel, I think" ([37], p. 102).

11 Lines such as the following seem written for Caeiro: "Reason' is the cause of our falsification of the evidence of the senses. In so far as the senses show becoming, passing away, change, they do not lie...” ([52], p. 46). 
Auden announces, heralding the emergence of post-Romanticism in Romanticism's wake, poetry makes nothing happen, it survives as a way of happening, a mouth.

\section{References and Notes}

1. Auden, Wystan Hugh. Selected Poems, edited by Edward Mendelson. New York: Vintage Books, 1979.

2. Auden, Wystan Hugh. Collected Poems, edited by Edward Mendelson. London: Faber and Faber, 2007.

3. Auden, Wystan Hugh. "The Public v. the late Mr William Butler Yeats." In The English Auden: Poems, Essays, and Dramatic Writings, 1927-1939, edited by Edward Mendelson. London: Faber and Faber, 1986.

4. Yeats, William Butler. Yeats's Poems, edited by A. Norman Jeffares. Basingstoke: Macmillan, 1996.

5. O'Neill, Michael. The All-Sustaining Air: Romantic Legacies and Renewals in British, American, and Irish Poetry since 1900. Oxford: Oxford University Press, 2007.

6. Coleridge, Samuel Taylor. The Complete Poems, edited by William Keach. London: Penguin, 1997.

7. Wordsworth, William. William Wordsworth (The Oxford Authors), edited by Stephen Gill. Oxford and New York: Oxford University Press, 1984.

8. Descartes, René. Discourse on Method and the Meditations, translated by Sutcliffe, F.E. London: Penguin, 1968.

9. Ameriks, Karl, and Dieter Sturma, eds. The Modern Subject: Conceptions of the Self in Classical German Philosophy. Albany: State University of New York Press, 1995.

10. Bowie, Andrew. Aesthetics and Subjectivity: From Kant to Nietzsche. Manchester and New York: Manchester University Press, 2003.

11. Klemm, David E., and Günter Zöller, eds. Figuring the Self: Subject, Absolute, and Others in Classical German Philosophy. Albany: State University of New York Press, 1997.

12. Pippin, Robert B. The Persistence of Subjectivity: On the Kantian Aftermath. Cambridge: Cambridge University Press, 2005.

13. Zahavi, Dan. Subjectivity and Selfhood: Investigating the First-person Perspective. Cambridge, MA and London: MIT Press, 2008.

14. Fichte, Johann Gottlieb. The Science of Knowledge, edited and translated by Peter Heath, John Lachs. Cambridge: Cambridge University Press, 1982. (Throughout, translations given will be based on this edition.)

15. Fichte, Johann Gottlieb. Sämmtliche Werke. Herausgegeben von I.H. Fichte, Band 1-8. Berlin: Veit \& Comp., 1845/1846.

16. Schlegel, Friedrich. Friedrich Schlegel's Lucinde and the Fragments, translated by Peter Firchow. Minneapolis: University of Minnesota Press, 1971. (Throughout, translations given will be based on this edition.)

17. Corby, James. "Emphasising the Positive: The Critical Role of Schlegel's Aesthetics." The European Legacy 15 (2010): 751-768. doi: 10.1080/10848770.2010.517260. 
18. Blanchot, Maurice. The Space of Literature, translated by Ann Smock. Lincoln, NE and London: University of Nebraska Press, 1989.

19. Lacoue-Labarthe, Philippe, and Jean-Luc Nancy. The Literary Absolute: The Theory of Literature in German Romanticism. New York: State University of New York Press, 1988.

20. Schlegel, Friedrich. Dialogue on Poetry and Literary Aphorisms, translated by Ernst Behler, Roman Struc. University Park: Pennsylvania State University Press, 1968.

21. Schlegel, Friedrich. Kritische Ausgabe. Herausgegeben von Ernst Behler unter Mitwirkung von Jean-Jacques Anstett und Hans Eichner. Erste Abteilung: Kritische Neuausgabe, Band 2. München, Paderborn, Wien: Schöningh; Zürich: Thomas, 1967.

22. Blanchot, Maurice. The Infinite Conversation, translated by Susan Hanson. Minneapolis and London: University of Minnesota Press, 1993.

23. Novalis. Philosophical Writings, translated by Margaret Mahony Stoljar. Albany: State University of New York Press, 1997.

24. Stevens, Wallace. Collected Poems. London: Faber and Faber, 1955.

25. Hulme, Thomas Ernest. Selected Writings, edited by Patrick McGuinness. Manchester: Fyfield Books, 2003.

26. Kermode, Frank. The Romantic Image. London: Routledge and Kegan Paul, 1966.

27. Hegel, Georg Wilhelm Friedrich. Aesthetics: Lectures on Fine Art, Vol. 1, translated by Knox, T.M. Oxford: Clarendon Press, 1998. (Throughout, translations given will be based on this edition.)

28. Hegel, Georg Wilhelm Friedrich. Vorlesungen über die aesthetik, zweiter theil. Berlin: Duncker und Humblot, 1843.

29. Agamben, Giorgio. The Man Without Content, translated by Georgia Albert. Stanford: Stanford University Press, 1999.

30. Heidegger, Martin. The Question Concerning Technology and Other Essays, translated by William Lovitt. New York: Harper and Row, 1977.

31. Heidegger, Martin. Introduction to Metaphysics, translated by Gregory Fried, Richard Polt. New Haven and London: Yale University Press, 2000.

32. Jacobi, Friedrich Heinrich. "Open Letter to Fichte." Translated by Diana I Behler. In Philosophy of German Idealism, edited by Ernst Behler. New York: Continuum, 2003, 119-141.

33. Heidegger, Martin. "The Origin of the Work of Art." In Poetry, Language, Thought, translated by Albert Hofstadter. New York: Perennial Classics, 2001.

34. Bernstein, Jay M. The Fate of Art: Aesthetic Alienation from Kant to Derrida to Adorno. Cambridge: Polity Press, 1997.

35. Hammermeister, Kai. The German Aesthetic Tradition. Cambridge: Cambridge University Press, 2002.

36. Gadamer, Hans-Georg. Philosophical Hermeneutics, translated by David E. Linge. Berkeley, Los Angeles and London: University of California Press, 1977.

37. Pessoa, Fernando. Fernando Pessoa \& Co.: Selected Poems, edited and translated by Richard Zenith. New York: Grove Press, 1998.

38. Critchley, Simon. "Surfaciality: Some Poems by Fernando Pessoa, One by Wallace Stevens, and the Brief Sketch of a Poetic Ontology." Gramma: Journal of Theory and Criticism 14 (2006): $109-129$. 
39. Bloom, Harold. The Western Canon. New York: Harcourt Brace, 1994.

40. Álvaro de Campos. "Poemas de Álvaro de Campos." http://www.dominiopublico.gov.br/ download/texto/pe000010.pdf (accessed on 20 September 2012).

41. Pessoa, Fernando. Selected Poems, translated by Jonathan Griffin. London: Penguin Books, 2000.

42 Hegel, Georg Wilhelm Friedrich. Vorlesungen über die aesthetik, erster theil. Berlin: Duncker und Humblot, 1842.

43. Pessoa, Fernando. The Selected Prose of Fernando Pessoa, edited and translated by Richard Zenith. New York: Grove Press, 2001.

44. Pessoa, Fernando. A Little Larger than the Entire Universe, edited and translated by Richard Zenith. London: Penguin Books, 2006.

45. Caeiro, Alberto. "Poemas Inconjuntos." http://www.dominiopublico.gov.br/download/texto/ pe000003.pdf (accessed on 20 September 2012).

46. Caeiro, Alberto. "O Guardador de Rebanhos." http://www.dominiopublico.gov.br/download/ texto/pe000001.pdf (accessed on 20 September 2012).

47. Geuss, Raymond. Outside Ethics. Princeton and Oxford: Princeton University Press, 2005.

48. Corby, James. "Fernando Pessoa's Post-Romantic Sense of the World." Comparative and Continental Philosophy 3 (2011): 165-181. doi: 10.1558/ccp.v3i2.165.

49. Nancy, Jean-Luc. The Sense of the World, translated by Jeffrey S. Librett. Minneapolis, MN and London: University of Minnesota Press, 1997.

50. Reis, Ricardo. "Poemas de Ricardo Reis." http://www.dominiopublico.gov.br/download/texto/ jp000005.pdf (accessed on 20 September 2012).

51. Nancy, Jean-Luc. The Birth to Presence, translated by Brian Holmes. Stanford: Stanford University Press, 1993.

52. Nietzsche, Friedrich. Twilight of the Idols and the Anti-Christ, translated by Hollingdale, R.J. London: Penguin Books, 1990.

(C) 2012 by the author; licensee MDPI, Basel, Switzerland. This article is an open access article distributed under the terms and conditions of the Creative Commons Attribution license (http://creativecommons.org/licenses/by/3.0/). 